\title{
SURVEY REPORT: AN ENGINEERING CONTROL EVALUATION FOR REDUCING EXPOSURE TO REFRACTORY CERAMIC FIBERS DURING SANDING
}

Conducted at Firelıne, Inc.

Youngstown, Ohı

\author{
PRINCIPAL AUTHORS \\ ${ }^{1}$ KevIn $H$ Dunn, M SEE, CIH \\ ${ }^{1}$ Stanley A Shulman, Ph D \\ ${ }^{2}$ Andrew B Cecala
}

${ }^{1}$ National Institute for Occupatronal Safety and Health

Division of Applied Research and Technology

And

${ }^{2}$ Pittsburgh Research Laboratory

626 Cochrans Mill Road

Pittsburgh, PA 15236

REPORT DATE

April 2003

FILE NO

EPHB 246-11a

U S DEPARTMENT OF HEALTH AND HUMAN SERVICES

Centers for Disease Control and Prevention

National Institute for Occupational Safety and Health

Division of Applied Research and Technology

4676 Columbia Parkway, R5

Cincınnatı, Ohю 45226 
STUDY SITE.

SIC CODE

STUDY DATES

STUDY CONDUCTED BY

EMPLOYER REPRESENTATIVES CONTACTED
FIRELINE, Inc

Youngstown, Ohı

3299

November 5, 2002

Kevin H Dunn, NIOSH

Andrew B Cecala, NIOSH

Barbara Burley, Vice President of Operations 


\section{DISCLAIMER}

Mention of company names and/or products does not constıtute endorsement by the Centers for Disease Control and Prevention (CDC) 


\section{INTRODUCTION}

On November 5, 2002, the National Institute for Occupational Safety and Health (NIOSH) conducted an engineernng control evaluation at Fureline, Inc in Youngstown, Ohıo Fireline devcloped a local exhaust ventilation system to capture and coliect atrbome refractory cerante fibers (RCF) dunng the sanding of vacuum-formed parts This system was installed on a disc sander and was evaluated by NIOSH along with representatives from the RCF manufacturer, Unufrax Corporation The pnmary objective of the study was to determine the operating conditions and effectuvcness of the engineering control which was designed and incorporated into the sanding process

\section{BACKGROUND}

Fireline Inc, is a small company that manufactures vacuum formed ceramuc fiber parts $A t$ the time of the survey, 67 workers were employed, 50 of these employees work in the plant while 17 work in the officc Fireline operates on a 3 shift basis with most workcrs (34) on the first shift The sanding arca 1 staffed 24 hours a day by one worker with an additional worker packing the material for shrpment

The manufacturing of various RCF products is composed of a number of tasks including, forming the part, drying, and finishing the part through sanding, sawing or other processes to meet the customer specifications Fireline purchases refractory ccramic fiber in bulk and vacuum forms the matcrals into various shapes as spccified by the customer Brass screened dies with perforated screen re-enforcements are made for the vanous shapes that are ordered The die is mounted on the appropnate dip machine The operator uses a foot pedal activated control switch to lower the die into the ceramic liber slurry tank A lumit switch is triggered when the die reaches the bottom of the tank to activate the vaccum A tmer activates a switch to remove the die from the slurry tank after the part has been formed around the die The operator sets the timer for the appropnate amount of time needed to form the part When formed, the operator removes the ceranme fiber part by hand from the die and places them into trays The tray of parts is then placed onto a conveyor beit and is dred in a radio wave oven After drying, the parts are transferred to the sanding station Once sanded, the part is removed from the station, inspected and packed mto a cardboard tray for shipping All RCF parts are finished on the disc sander

\section{PROCESS/ENGINEERING CONTROL DESCRIPTION}

\section{Disc Sander/Engineering Control Descruptıon}

A floor-standing disc sander made by Firelıne was used for evaluation The sanding wheel was 20 inches in diameter and operated at a speed of 1150 revolutıons per minute (rpm) The zirconium 50 grtt paper was manufactured by Arc Abrasive (Troy, Ohıo) The pedestal disc sander was outfitted with a local exhaust ventilation (LEV) system (see Figures 1 and 2) An alumınum shroud was constructed which enclosed the entire disc with only a small cutout opening to allow for the part to 
be sanded The opening in the shroud is adjustable to allow for the sanding of parts of various dimensions The part used for evaluation was a ceramic fiber sleeve which houses and protects an instrumentation probe used to test process parameters, such as temperature of molten metals, in foundry operations The RCF slecve was approximately 2 mches diameter and 4 inches in length

A ventilation duct takc-off is located on the lower rear of the sander and uses a 6-inch flexible duct and connects into an aluminum ngid main exhaust duct which provides exhaust outlets for other workstations withen the plant A pitol tube traverse was performed in the 6 inch rigid duct to determine the exhaust air flow rate for the shroud system The velocity in the duct was measured to be 5,400 feet per minute yrelding an overall exhaust flow rate of 1,060 cubic feet per minute

\section{Process Description}

The sanding process 1s partially automated and is performed according to the following steps

1) The operator pulls the unfinished part from a box and places the part on a spindle by hand

2) The operator uses a foot pedal to activate a pneumatic aur cylinder that causes the spindle to rotate dnving the part into the sanding wheel

3) The part is sanded to the desired dimensions and the spindle returns to the initial position

4) The part is removed from the spindle and packed by hand in a box for inspection and shıpping

The cycle time controls the amount of time that the part is in contact with the sanding wheel and is adjustable by the operator This adjustment allows the operator to work at a pace that is comfortable and cfficient The cyclc time used durng the tral runs was 17 seconds while the typical cycle time used by an expenenced operator is 075 seconds

\section{METHODS}

\section{Evaluation of the Effectiveness of the Control}

Three trials were conducted both with the exhaust ventilation system on (a $\mathrm{k}$ a control-on) and with the system off (control-off) The same operator was uscd in each (rial to minımize vanability between trials Each control-on trial lasted for approximately 10 munutes allowing the operator to sand berween 88 and 92 parts When the control was turned off, the trial duration was shortened to 5 minutes and 46 pleces due to concern for overloading the sample fillers The control-off runs were conducted after first shıft when the work arca was vacated Following the completion of each run, the ventlation system was turned on and the area was cleaned using a HEPA vacuum to minimize contamination betwecn runs The ambient air dust concentration was monitored using a Met Onc, modcl 227B, hand-held particle counting instrument manufactured by Pacific Scicntific Instruments (Grants Pass, OR)

The Met One was used to determune when ambient dust concentrations had reached background levels proor to initjating a new trial 


\section{Personal and Area Sampling}

Personal samples were collected using SKC Inc Arrchek 2000 model 210-2002 sampling pumps (E1ghty Four, PA) Since concentrations were not known a prion, 2 personal samples were collected on the opcrator at flow rates of 2 and 3 liters per munute (1pm) This was done to collect a quantifiable amount of fibers while attempting to munnuze the possibility that the fillers would be overloaded An arca sample located close to the process was collected at a flow ratc of $15 \mathrm{lpm}$ using a Gillan (West Caldwell, NJ) Aircon 2 high-volume arr pump (see Figures 3 and 4) Personal and ared samples for fibers werc collected on 25 millımeter (mm) diametcr, mixed cellulose cster, 08 $\mu \mathrm{m}$ pore size filters The samplers were 3-prece cassettes with a $50 \mathrm{~mm}$ electrically conductive extension cowl Samples were analyzed for fibers by phase contrast microscopy according to NIOSH Method 7400, "B" counting rules'

\section{RESULTS}

The results for the individual samples are shown in Table l The differences between the personal samples collected at each of the given sample flow rates $(2 \mathrm{or} 3 \mathrm{lpm})$ were minor and did nol affect the estimates of reduction The personal breathing zone avcrage concentration decreased from 44 libcrs/cubic centumelor ( $\mathrm{f} / \mathrm{cc}$ ) with the control-off to $035 \mathrm{f} / \mathrm{cc}$ with the control-on Figure 5 shows the average fiber concentrations measured on the lapel and the associaled standard deviation for the control-on and control-off trials

\section{DISCUSSION}

The pedestal disc sander operation is used frequently in RCF processing to obtain a desired product dimension In disc sanding, the surface of the RCF workpiece is abraded to yield the proper profile The friction between the whecl/belt and the workpicce results in the release of particles and fibers from the workpiece These particles are ejected at high speeds along a path tangential to the rotation of the wheel The respirable particles, if not capturod, could be carried into the breathing zone of the worker resulting in exposure to the RCF fibers and dust particles

The use of a nearly complctcly enclosing shroud along with an exhaust flow rate of approximatcly $1000 \mathrm{cfm}$ reduced the operator exposure by $99 \%$ (lower $95 \%$ Con lidence Interval $=99 \%$ )

Following the completion of the control-on runs, a worker was sampled for a period of 47 minutes (see Table I) The personal breathing zone concentration for the worker measured durng this pernod was $025 \mathrm{f} / \mathrm{cc}$ The results of thus sample showed that the control was very effective at reducing the fiber concentration in the personal breathing zone even at the much ligher production rate of part processing ( 30 parts per minute for the worker versus 9 parts per minute for the expenimental runs)

The exhaust flow rate of $1,000 \mathrm{cfm}$ used is higher than that specified by the Industral Ventilation Manual which recommends an exhaust flow rate of $550 \mathrm{cfm}$ for an 18-26 inch diameter sandıng disc (desıgn plate VS-95-12) ${ }^{2}$ However, this system was evaluated while other LEV systems which are also served by the same cxhaust fan were not in operation It is important to consider the impact of 
the reduced flow rates that will be encountered when more than one LEV system are operating simultaneously Reportedly, only one operation uses the ventilation system dunng a lypical day However, if more than one workstation rcquiring the use of the ventılation system is opcrated at the same time as the disc sanding operation, a further cvaluation should be conducted The use of more than one workstation at one time will reduce the arflow rate to each individual workstation and may result in reduced collection efficiency or inadequate duct transport velocity

\section{CONCLUSIONS AND RECOMMENDATIONS}

Engincering controls can be manufactured and installed on standard disc sanders and can significantly reduce operator exposure Howcver, a kcy to their effectiveness is that the system must be designed and mantained properly Thorough system checks should be performed perrodically to venfy that the system is operating as designed These checks should include visual inspection of the work area and the ducling to check for any damage to the shroud or ducting The work area should be kept clean and the ductıng should be checked for settled fibers and dust Fibers and dust buld-up in the ducts are signs of inadequate transport velocity Also, checks of statte pressure and duct flow rates should be performed and compared to the values speofied in the ACGIH Vontulation Manual The most pertinent evaluation of system performance is the measurement of worker exposure Worker exposure to RCF matenals should contunuc to be montored on at least an annual basis to vernfy that the system is contınung to provide good control of arbome fibers

Engineering controls provide an eflective method for reducing worker exposure to RCF fibers The implementation of enginecring controls can have a beneficial umpact on worker exposure The implementation of a LEV system as descrubed in this paper reduced the operator exposure by two orders of magnitude The development and test of well-desıgned LEV control systems can provide valuablc unfomation to the large number of customers/end users of RCF materials

\section{ACKNOWLEDGMENTS}

The authors gratefully acknowledge Ms Barbara Burley of Fireline, Inc for her coopcration and support during this evaluation We would also like to acknowledge Mr Robert Vitucci of Firelıne for his work in developing the engineering control utilized in this evaluation In addition, we would hike to thank $\mathrm{Mr}$ Dean Venturin of Unıfrax Corporation for his help in conducting this evaluation and his continucd cfforts in working with NIOSH to highlight the importance of using engineenng controls to minumize exposures in the RCF industry 


\section{REFERENCES}

I National Institute for Occupational Safety and Health (NIOSH) Asbcslos and olher fibers by PCM Method 7400 In NIOSH Manual of Analytucal Methods 4th ed Washington D C Government Prntung Office, 1994

${ }^{2} A C G I H(2001)$. Industria] Ventilation A Manual of Recommended Practice $24^{\text {th }} \mathrm{Ed}$

Cincinnati American Conferciec of Governmental Industrial Hygıensts (ACGIH), 2001 
Table I Alrborne RCF Sample Results

\begin{tabular}{|c|c|c|c|c|c|c|}
\hline $\begin{array}{l}\text { Run } \\
\text { no. }\end{array}$ & $\begin{array}{l}\text { Control } \\
\text { Status }\end{array}$ & $\begin{array}{l}\text { Sample } \\
\text { Location }\end{array}$ & $\begin{array}{l}\text { Flow } \\
\text { Rate } \\
(1 \mathrm{pm})\end{array}$ & $\begin{array}{c}\text { Elapsed } \\
\text { Time } \\
\text { (mın) }\end{array}$ & $\begin{array}{c}\text { No of } \\
\text { Pleces } \\
\text { Processed }\end{array}$ & $\begin{array}{c}\text { Concentration } \\
(\mathrm{f} / \mathrm{cc})\end{array}$ \\
\hline 1 & On & Lapel & 2 & 10 & 88 & 065 \\
\hline 1 & On & Lapel & 3 & 10 & 88 & 059 \\
\hline 1 & On & Area & 15 & 10 & 88 & 036 \\
\hline & & & & & & \\
\hline 2 & On & Lapel & 2 & 1068 & 92 & 022 \\
\hline 2 & On & Lapel & 3 & 1068 & 92 & 028 \\
\hline 2 & On & Area & 15 & 1068 & 92 & 011 \\
\hline & & & & & & \\
\hline 3 & On & Lapel & 2 & 95 & 92 & 022 \\
\hline 3 & On & Lapel & 3 & 95 & 92 & 016 \\
\hline 3 & On & Area & 15 & 95 & 92 & 012 \\
\hline Worker & On & Lapel & 3 & 47 & 1440 & 025 \\
\hline & & & & & & \\
\hline 4 & Off & Lapel & 2 & 43 & 46 & 3792 \\
\hline 4 & Off & Lapel & 3 & 43 & 46 & 3528 \\
\hline 4 & Off & Area & 15 & 43 & 46 & \\
\hline 5 & Off & Lapel & $\overline{2}$ & $\overline{441}$ & 46 & 5020 \\
\hline 5 & Off & Lapel & 3 & 441 & 46 & 3699 \\
\hline 5 & Off & Area & 15 & 441 & 46 & \\
\hline & & & & & & \\
\hline 6 & Off & Lapel & 2 & 4333 & 46 & 5305 \\
\hline 6 & Off & Lapel & 3 & 4333 & 46 & Overloaded \\
\hline 6 & Off & Area & 15 & 4333 & 46 & Overloaded \\
\hline
\end{tabular}


Figure 1 Disc Sander with Shroud and Un-Sanded Ceramıc Sleeve Part

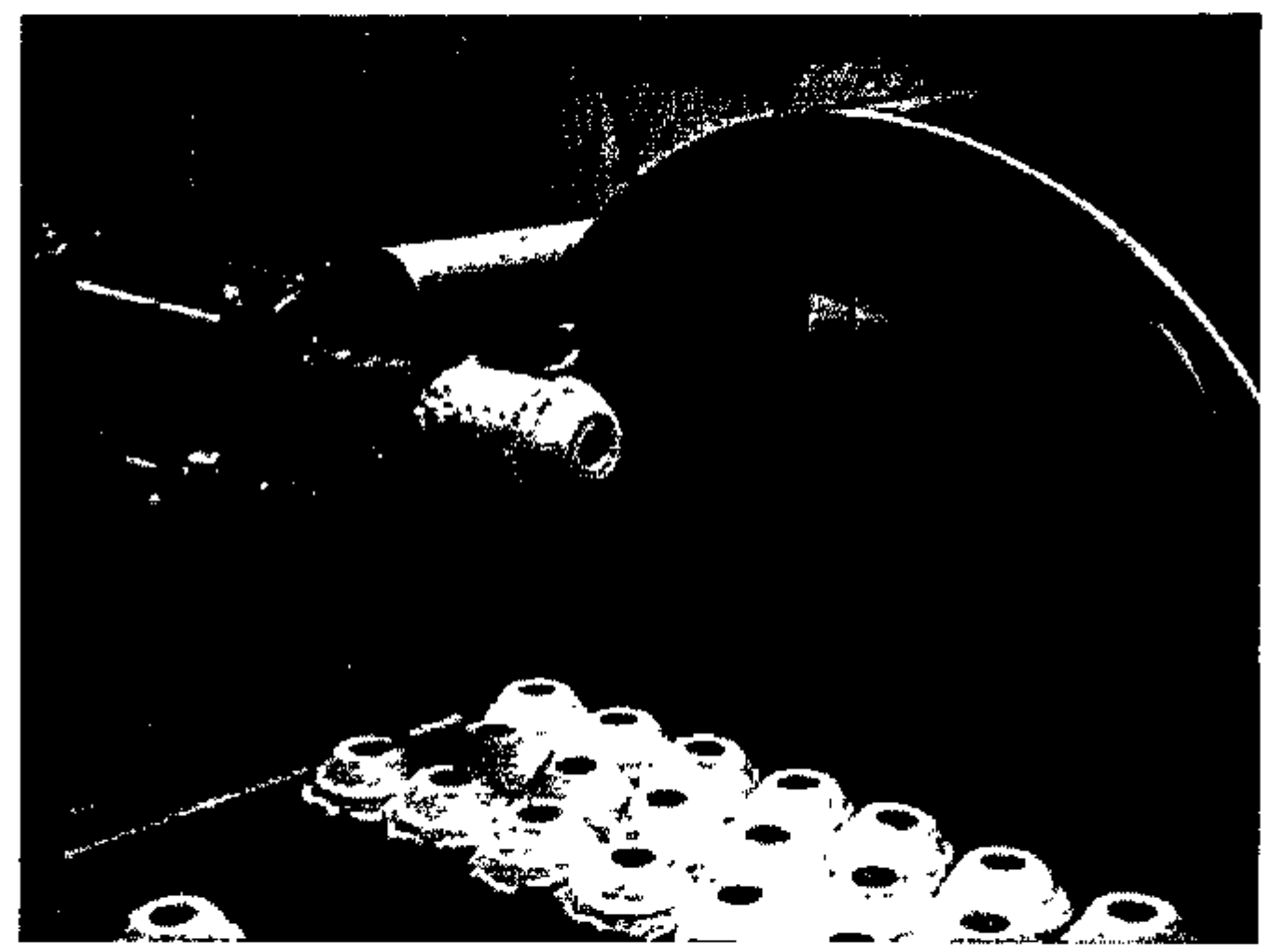


Figure 2. Sketch of Disc Sander with Ventilation System Detals

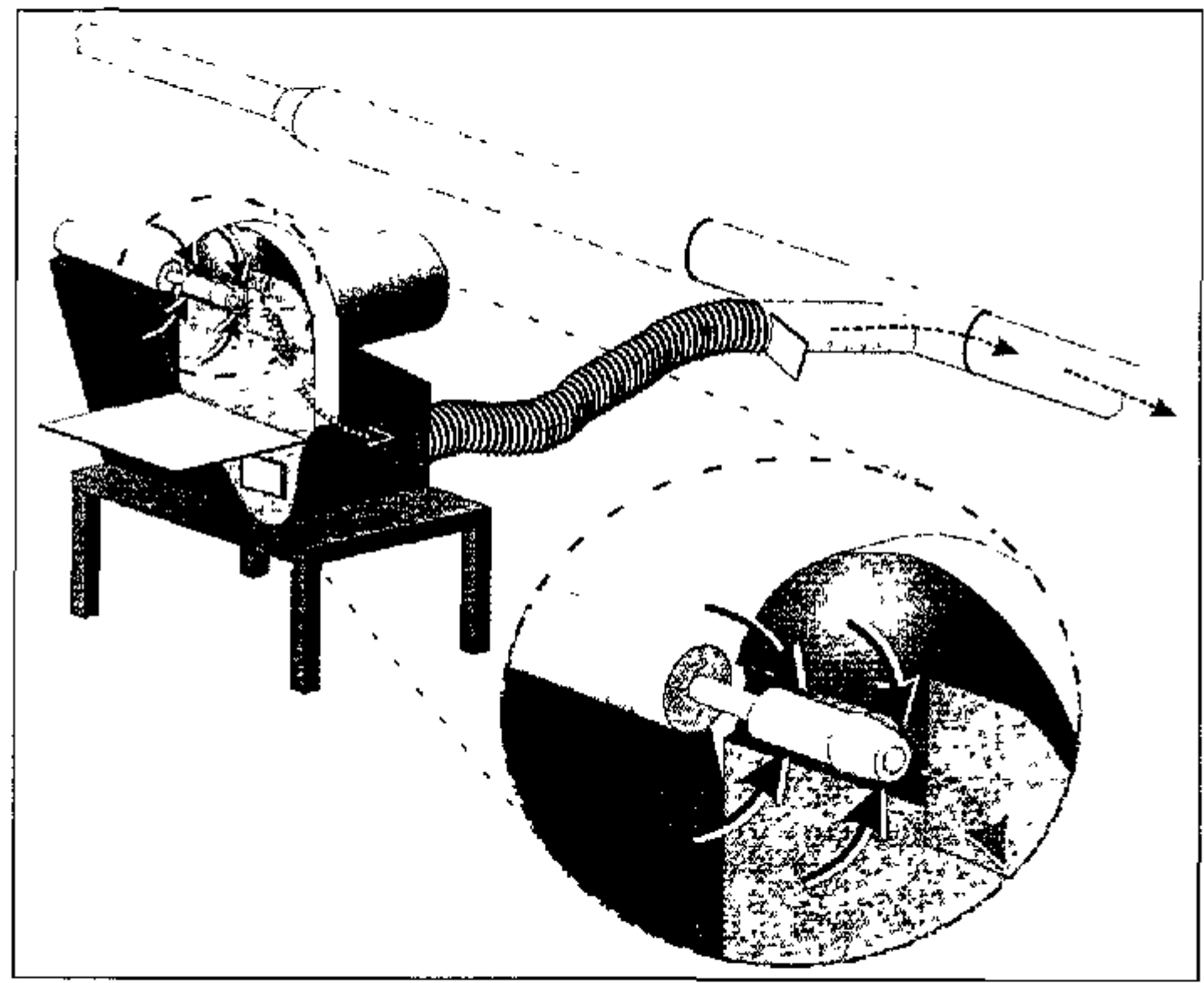


Figure 3 Sketch of Worker and Aır Sampler Orientation Durıng Tral Runs

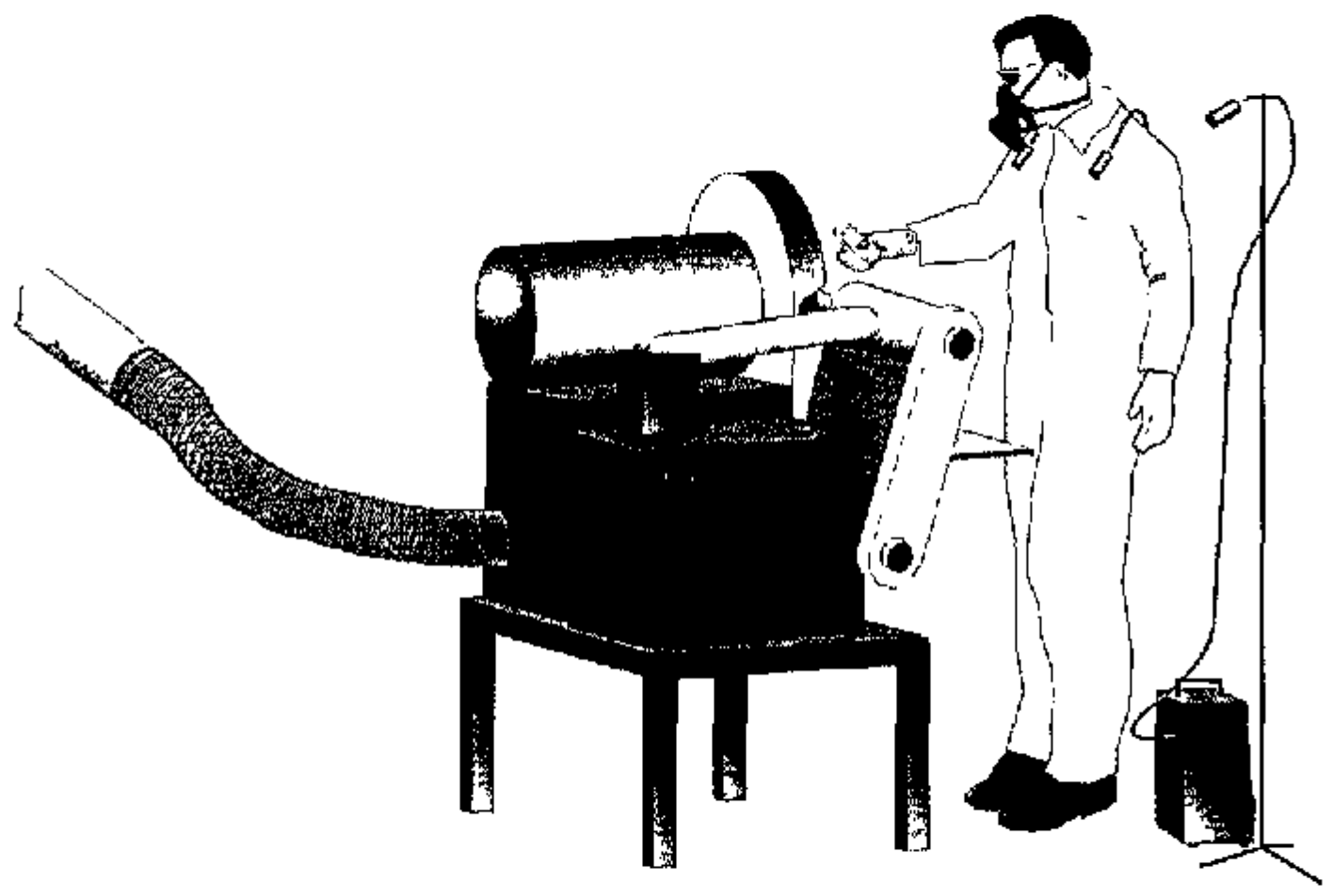

Figure 4 Photo of Trial Runs with Area and Personal Samplers during a Control-Off Run

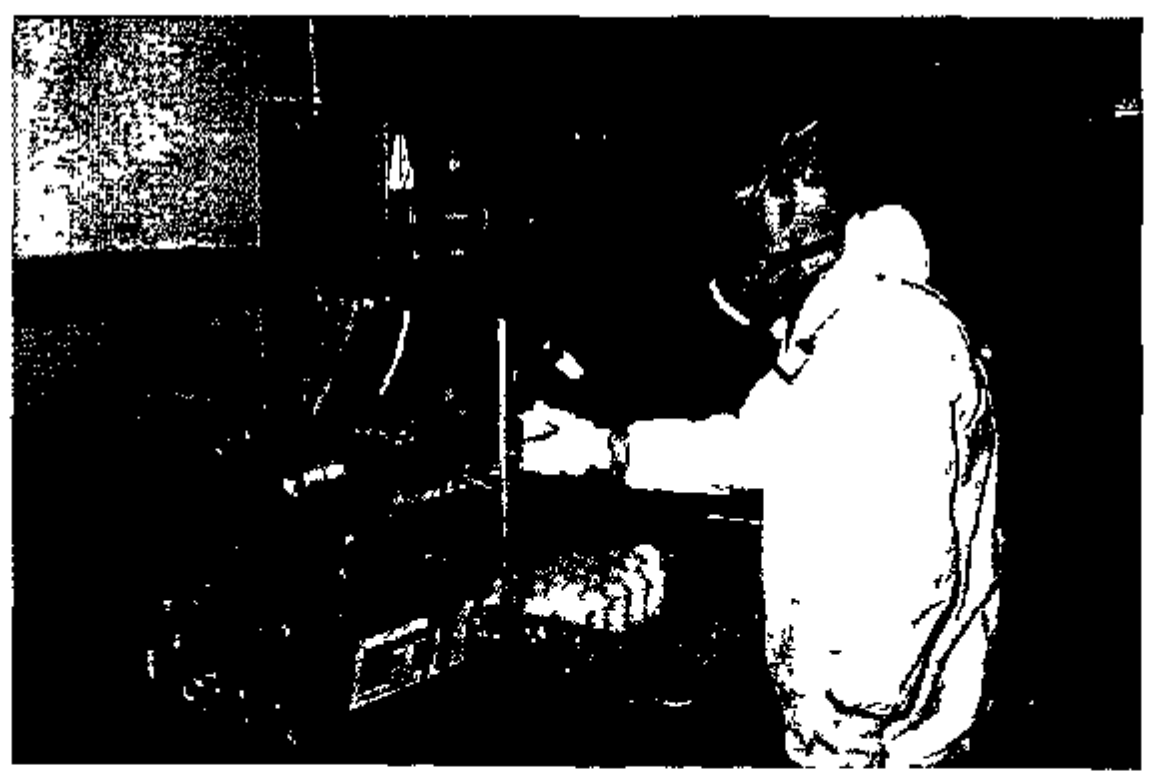


Figure 5. Companson of average personal RCF concentrations for control-on and control-off runs

Personal Fiber Concentrations Average concentrations based on worker lapel samples

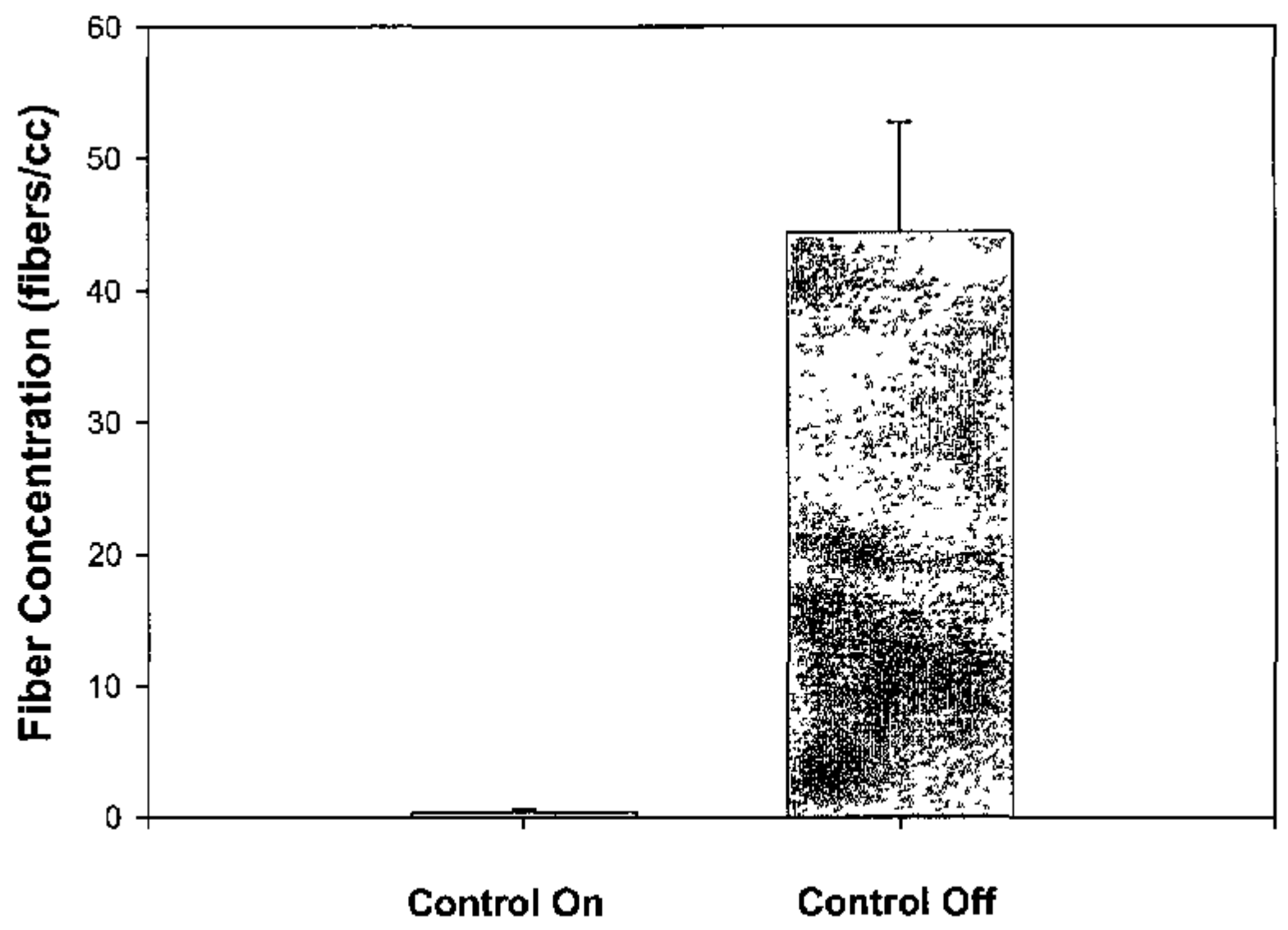

